2014

\title{
Family Courts are Here to Stay, So Let's Improve Them
}

Barbara A. Babb

University of Baltimore School of Law, bbabb@ubalt.edu

Follow this and additional works at: http://scholarworks.law.ubalt.edu/fac_articles

Part of the Family Law Commons

\section{Recommended Citation}

Babb, Barbara A., "Family Courts are Here to Stay, So Let's Improve Them" (2014). Articles. 3.

http://scholarworks.law.ubalt.edu/fac_articles/3

This Article is brought to you for free and open access by the Faculty Scholarship at ScholarWorks@University of Baltimore School of Law. It has been accepted for inclusion in Articles by an authorized administrator of ScholarWorks@University of Baltimore School of Law. For more information, please contact snolan@ubalt.edu. 


\title{
FAMILY COURTS ARE HERE TO STAY, SO LET'S IMPROVE THEM
}

\author{
Barbara A. Babb \\ [W] hile the challenges of a contemporary ... family court docket may be fierce, we can unquestionably \\ find ways to meet them and do better. I am simply unwilling to adopt a despairing and defeatist attitude the \\ "nothing works" or — put another way- “everything stinks," but don't change a thing. ${ }^{1}$
}

\section{INTRODUCTION}

This article is an invited response to the White Paper of the Institute for the Advancement of the American Legal System's Honoring Families Initiative on the court and separating and divorcing families. ${ }^{2}$ While the White Paper explores many topics, including family court functions, the limitations of the adversary process, the effects of divorce and separation on children and parents, and court and community collaborations, among others, this article focuses on the family court itself-its mission, its function, and its structure. Given the increasing numbers of people using the courts to resolve their family legal disputes, this perspective is important. ${ }^{3}$ For example, in Maryland during fiscal year 2013, forty-four percent of the total trial court filings involved family and juvenile cases, exceeding the portion devoted to either criminal or other civil cases. ${ }^{4}$ In fact, as the White Paper points out, "[t]he family courts have, in effect, become an emergency room for family problems when separating and divorcing parents have nowhere else to turn for help in addressing their problems with each other and their children." With that in mind, family courts likely are not going to disappear. Thus, they are worthy of our efforts to structure or restructure them so that they are as helpful to children and families as possible.

\section{THE NEED FOR AN UNDERLYING THEORETICAL FOUNDATION TO GUIDE THE FAMILY COURT PROCESS}

Because of the complex and intimate nature of family law cases, and because of the unique and powerful impact courts have by intervening explicitly in families' and children's lives, the legal process must operate effectively. The White Paper authors suggest employing processes that are "more accessible and more responsive to children, parents, and families." For nearly two decades, I have advocated that family courts adopt both a therapeutic and a holistic approach to court structure and processes, as well as to family law decision making. ${ }^{7}$ I have suggested the application of therapeutic jurisprudence and the ecology of human development as a means to accomplish this more responsive approach.

\section{THERAPEUTIC JURISPRUDENCE}

Professor David Wexler, one of the co-founders with the late Professor Bruce Winick of the concept of therapeutic jurisprudence, defines it as follows:

Correspondence: bbabb@ubalt.edu 
Therapeutic jurisprudence is the study of the role of law as a therapeutic agent. It looks at the law as a social force that, like it or not, may produce therapeutic or anti-therapeutic consequences. Such consequences may flow from substantive rules, legal procedures, or from the behavior of legal actors (lawyers and judges). The task of therapeutic jurisprudence is to identify - and ultimately to examine empirically - relationships between legal arrangements and therapeutic outcomes. The research task is a cooperative and thoroughly interdisciplinary one. ${ }^{8}$

Therapeutic jurisprudence applied in the family law context means that courts must focus on achieving outcomes that positively affect and even improve the lives of individuals, children, and families involved in family law proceedings. Each individual's viewpoint is important to determine what constitutes a therapeutic outcome; thus, it is something attorneys and decision makers must identify and attempt to honor. As I have stated, "[i]n the field of family law, therapeutic jurisprudence should strive to protect families and children from present and future harms, to reduce emotional turmoil, to promote family harmony or preservation, and to provide individualized and efficient, effective justice." I also believe that this approach "has the potential to facilitate problem-solving and to positively enhance the quality of the parties' daily lives, thereby rendering a more effective outcome for individuals and families." 10

\section{THE ECOLOGY OF HUMAN DEVELOPMENT}

To account for the many influences on the lives of families and children, I have advocated for the application of a theoretical research paradigm from the social sciences, the ecology of human development, which is Professor Urie Bronfenbrenner's model. ${ }^{11}$ This approach helps all those involved with the family law process, including lawyers, judges, services providers, and litigants themselves, to understand comprehensively and to account for all the legal and nonlegal issues the parties face. This holistic approach "promotes consideration of the interaction among individuals, institutions, and the social environment; assists with the identification of problems; and contributes to the development of solutions." ${ }^{\prime 2}$ The ultimate aim is to identify and strengthen the connections among and between these influences to improve families' and children's functioning. ${ }^{13}$

According to Bronfenbrenner, the "microsystem" is the most immediate context within which people live - the husband-wife relationship, the parent-child relationship, and sibling relationships. ${ }^{14}$ The "mesosystem" is the relationship between microsystems, such as the school-home connection and the workplace-home connection. ${ }^{15}$ The "exosystem" is a setting that has power over one's life but in which one does not participate, such as the influence of a parent's workplace on the child's life. ${ }^{16}$ Finally, the "macrosystem" is the ideology of a culture or subculture-its social policy. ${ }^{17}$

If this approach is applied to family law lawyering, services provision, and decision making, connections that may go unnoticed are likely to be revealed. Significant influences on families' and children's lives can be identified. Connections and interconnections can be enhanced, and the perspective offers a holistic view of families' and children's functioning. Because the application of this perspective encourages consideration of the variety of influences on each family, "[t]his expanded knowledge permits all family justice system professionals to intervene more effectively, thereby promoting more therapeutic outcomes for families and children." 18

\section{RELATIONSHIP OF THIS THEORETICAL FOUNDATION TO THE WHITE PAPER}

The White Paper authors state that the aim of their work "is to advance empirically informed models for dignified and fair processes for the resolution of divorce and child custody cases ..."19 They indicate that their first project is identifying "[p]rinciples that would undergird in-court dissolution or child custody cases," ${ }^{20}$ and they argue that the principles should be "research informed." 21 They also suggest "a set of principles that frame an action plan" 22 and invite further input by other professionals.

Indeed, both therapeutic jurisprudence and the ecology of human development are heavily research based and empirically tested. ${ }^{23}$ Both theories are applied internationally and across a wide array of 
subject matter areas. ${ }^{24}$ As I have advocated elsewhere since $1997,{ }^{25}$ I believe that these two theories ought to undergird the work of all professionals involved in the family justice system. As such, I urge the White Paper authors to consider proposing explicitly the adoption of therapeutic jurisprudence and the ecological approach as the framework for their work.

\section{EXAMINING THE FAMILY COURT}

The White Paper authors correctly state that "[t]he court is the basic institution assigned the task of resolving disputes" 26 in family law cases. They define the court's "essential core functions in disputed cases" 27 as "creating and enforcing orders." 28 They also add that "[p]rotecting victims from violence, holding abusers accountable, and, ideally, setting parties on a course of rehabilitation are core functions of the legal system." 29 The authors indicate that "[t]he court undertakes these core functions within the framework of the adversarial process. Court proceedings must be consistent with due process of law, as judicial orders entered ... involve important legal rights and constitutional values." ${ }^{30}$ They criticize the current family justice system, however, as "overwhelmed with a deluge of cases and diminishing resources that threaten its ability to perform its core functions" ${ }^{\prime 31}$ and emphasize that the adversary process does "not meet the needs of many reorganizing families who look to the courts for solutions." ${ }^{32}$ They ask, "How can family courts be organized and supported to best perform their core functions in an era of shrinking resources?"33

For decades, I have advocated a specific type of family justice system reform, namely, the creation of Unified Family Courts that employ a therapeutic and a holistic perspective. ${ }^{34} \mathrm{I}$ believe that this court model effectively answers the authors' question. Having discussed already (above) the foundations of this perspective - that is, therapeutic jurisprudence and the ecology of human development-I turn now to my blueprint to create Unified Family Courts. This court model also addresses and incorporates many of the reforms suggested by the White Paper authors.

\section{A BLUEPRINT TO CREATE A UNIFIED FAMILY COURT}

As I have described in previous scholarship, ${ }^{35}$ a Unified Family Court is a single court system with comprehensive subject matter jurisdiction over all cases involving children and relating to the family, including family breakup, child access, domestic violence, financial issues, creation and termination of the parent-child relationship, child abuse and neglect, and juvenile delinquency, among others. Under a Unified Family Court's auspices, the goal of the family justice system and the aim in family law proceedings is to provide a comprehensive resolution of a case tailored to the individual family's legal, personal, emotional, and social needs. The court accomplishes this outcome through judicial action, informal court proceedings, alternative dispute resolution, and appropriate social services.

A Unified Family Court addresses problems that exist in many family justice systems, such as time-consuming, expensive, duplicative court processes; inadequate attention to child-related issues; insufficient use of alternative dispute resolution; lack of coordination of legal issues involving the same family; lack of expertise of some family court judges; and inadequate attention to the needs of the poor and self-represented litigants. ${ }^{36}$ The implementation of the Unified Family Court model often results in increased court efficiency and more coordinated, responsive decision making.

I have written extensively about the elements to include in the design of a Unified Family Court. ${ }^{37}$ To summarize, a Unified Family Court should consist of the following:

- a specialized court structure that is either a separate court or a division or department of an existing court and is established at the same level and receives the same resources/support as a generalist court;

- comprehensive subject matter jurisdiction over the full range of family law cases, including juvenile delinquency and child welfare; 
- a case management and case processing system that includes early and hands-on contact with each family law case and a judicial assignment system that results in the family appearing before one judge for the completion of one case or one case management team;

- an array of court-supplied or court-connected social services that meet litigants' nonlegal needs, particularly those that exacerbate family law problems; and

- a user-friendly court that is accessible to all family law litigants, including the large volume of self-represented litigants. ${ }^{38}$

By incorporating therapeutic jurisprudence, the Unified Family Court's aim is to improve the lives of families and children who find themselves within the family justice system. Applying an ecological framework enables and ensures that the court addresses families' problems holistically, and it offers decision makers an approach to comprehend fully the true nature of a family's functioning and its legal and nonlegal problems. "Thus, this interdisciplinary perspective from both the law and the social sciences, coupled with the blueprint to design a Unified Family Court, provides a framework around which to design or redesign a more effective family justice system." ${ }^{39}$ As Maryland's former Chief Judge Robert M. Bell has written:

[W]e have finally come to realize, that the effective resolution of legal disputes within a family requires a fundamental shift from the traditional adjudication focus to a more holistic, therapeutic model that attempts to improve the lives of families and children in substantive ways. To achieve this new paradigm, there must be a confluence of access to coordinated and comprehensive legal and social services, efficient case processing and management, and a more widely accessible court system. ${ }^{40}$

\title{
THE WHITE PAPER'S DISCUSSION OF FAMILY COURTS
}

The White Paper authors reference the family court throughout their piece.

\begin{abstract}
We assume that the core functions of the courts are protection, enforcement, and fact-finding. Those are functions that no other entity can provide. Courts must continue to offer protection for victims, disputed fact-finding where necessary, and enforcement of orders. They must also receive adequate resources to perform these functions efficiently and fairly. If choices have to be made, use of the court's time in family cases will be focused on the cases where the need for judicial intervention is the highest. Family court judges must have the opportunity for training and education about child development, family dynamics, and dispute resolution before they rotate into a family court division. No amount of community involvement or service diversion will change the need for these basic services. ${ }^{41}$
\end{abstract}

Indeed, the authors themselves admit that the need for the family court remains constant. Can courts decide, however, which cases to handle? While I support the notion that courts can decide how quickly to deal with a particular case (generally through the application of a system of differentiated case management),${ }^{42}$ I submit that courts are not free to decide whether they will process a properly filed case. All citizens are entitled to have their legitimate family legal needs addressed in some manner by the family court. These issues often have their foundations in both state statutory law and rules and the U.S. Constitution. Giving the court the power to decide whether it will handle a particular case is likely to result in unequal dispensation of justice - the haves and the have-nots. For example, given the difficulty courts often have dealing with self-represented litigants, ${ }^{43}$ if courts have the ability to choose which cases to handle, it is quite likely that many may decide against dealing with unrepresented parties. Thus, we must not reach a point where the only way to ensure a fully functioning family court system is by giving courts the power to decide which cases they wish to address.

Clearly, attention must be paid to create more efficient, effective family courts that enable court access for all litigants. It appears that the White Paper authors agree with this notion, as they state, "Judicial resources need to be promptly and consistently available to families for the core functions of fact finding, protection, and enforcement. Systems should be designed to assure that access." ${ }^{44}$ Yet, 
the authors follow by saying that "[t]he balance of families in transition does not need to be in the courts. They require access to services that facilitate problem solving and future planning, but those services need not be provided by the courts, so long as sufficient quality control is in place." ${ }^{45}$

As I indicated, one of the elements of a Unified Family Court does just that - it both provides certain vital services and links families to existing community services. Further, who gets to decide what "sufficient quality control" is? Presently, courts are held accountable to their citizens in many ways. For example, in some jurisdictions, judges and certain court personnel are elected. Likewise, in all jurisdictions, courts strive to maintain public trust and confidence in the justice system. Those and other means of quality control of the justice system do not exist for the public once legal matters are removed from the courts. Should people have the ability to choose whether to remove certain legal matters from the courts? Assuming they are provided sufficient background information as to the advantages and disadvantages about an out-of-court process, this option may be appropriate for certain family legal issues. What renders the out-of-court possibilities problematic is when they are the only option available to the litigants - when litigants effectively are foreclosed from access to the courts. That is just not a solution to whatever problems exist.

\section{CONCLUSION}

The White Paper authors have raised interesting issues about the fundamental role of the family justice system. I agree with their suggestions that the family courts are in need of reform, and I have offered both an underlying theoretical foundation for and a blueprint to do just that. We must never lose sight, however, of the importance of the fact that courts remain the one place in society where everyone is equal. At the same time, as we work to reform family courts, we must safeguard for all the ability to access the family justice system.

\section{NOTES}

1. Judith S. Kaye, Delivering Justice Today: A Problem-Solving Approach, 22 YALE L. \& PoL'y REV. 125, 147 (2004).

2. Rebecca L. Kourlis et al., IAALS' Honoring Families Initiative: Courts and Communities Helping Families in Transition Arising from Separation or Divorce, 51 FAM. CT. REV. 351 (2013).

3. Family law matters are defined to include divorce, annulment, and property distribution; child custody and visitation; alimony and child support; paternity, adoption, and termination of parental rights; juvenile cases (delinquency, child abuse, and child neglect); domestic violence; criminal nonsupport; name change; guardianship or minors and disabled persons; and withholding or withdrawal of life-sustaining medical procedures, involuntary admissions, and emergency evaluations. See, e.g., DEL. CODE ANN. tit. $10 \S \S 921-25,927-28$ (West 2012).

4. See Admin. Office of the Courts, Court Operations Dept., Maryland Judiciary Annual Statistical Abstract Fiscal Year 2013 (2013), available at http://www.courts.state.md.us/publications/annualreport/reports/2013/fy2013statisticalabstract.pdf

5. Kourlis et al., supra note 2, at 356.

6. Id. at 353 .

7. Barbara A. Babb, An Interdisciplinary Approach to Family Law Jurisprudence: Application of an Ecological and Therapeutic Perspective, 72 IND. L.J. 775 (1997) [hereinafter Interdisciplinary Approach]; Barbara A. Babb, Fashioning an Interdisciplinary Framework for Court Reform in Family Law: A Blueprint to Construct a Unified Family Court, 71 S. CAL. L. REV. 469 (1998) [hereinafter Interdisciplinary Framework]; Barbara A. Babb, Maryland's Family Divisions: Sensible Justice for Families and Children, 72 MD. L. REV. 1124 (2013); Barbara A. Babb, Reevaluating Where We Stand: A Comprehensive Survey of America's Family Justice Systems, 46 FAM. CT. REV. 230 (2008); Barbara A. Babb \& Judith D. Moran, Substance Abuse, Families, and Unified Family Courts: The Creation of a Caring Justice System, 3 J. HEALTH CARE L \& POL'Y 1 (1999); Barbara A. Babb \& David B. Wexler, Therapeutic Jurisprudence, in ENCYClOPEDIA OF CRIMINOLOGY AND CRIMINAL JusticE (Gerben Bruinsma \& David Weisburd eds., 2014); Barbara A. Babb, Where We Stand: An analysis of America's Family Law Adjudicatory Systems and the Mandate to Establish Unified Family Courts, 32 FAM. L.Q. 31 (1998).

8. David B. Wexler, Putting Mental Health Into Mental Health Law: Therapeutic Jurisprudence, in ESSAYS IN THERAPEUTIC JuRISPRUDENCE 3, 8 (David D. Wexler \& Bruce J. Winick eds., 1991) (citation omitted).

9. Babb, Interdisciplinary Approach, supra note 7, at 800 .

10. Id. at 802 .

11. Babb, supra note 7 . 
12. Gary B. Melton, Child Advocacy: Psychological Issues and Intervention 64 (1983); see also Gary B. Melton et al., Community Mental Health Centers and the Courts: An Evaluation of Community Based Forensic SERVICES (1985) (this book offers a comprehensive examination of the relationship between the mental health professions and the legal system, with suggestions for strengthening that relationship).

13. James Garbarino \& Robert H. Abramowitz, Sociocultural Risk and Opportunity, in CHILDREN AND FAMILIES IN THE SOCIAL ENVIRONMENT 35 (James Garbarino et al. eds., 2d ed. 1992). Application of an ecological perspective may present challenges:

It would be easy to cast aside the many interconnections and pretend that there is just the developing child, or just the family as a social unit, or just the community power structure, or just the professional delivering human services. It would be easy, but we believe it would not be enough. Rather, we seek to capture the whole tangled mass of relationships connect child, family, and social environment.

James Garbarino \& Mario T. Gaboury, An Introduction, in CHILdREN AND FAMILIES IN THE Social ENVIRONMENT 1 (James Garbarino et al. eds., 2d ed. 1992).

14. See Urie Bronfenbrenner, the ECology of Human Development 7, 22 (1979).

15. Id. at $7-8,25$.

16. Id.

17. James Garbarino \& Robert H. Abramowitz, The Ecology of Human Development, in CHILDREN AND FAMILIES IN THE SOCIAL ENVIRONMENT 11, 27 (James Garbarino ed., 2d ed. 1992).

18. Problem Solving Courts: Social Science and Legal Perspectives 73 (Richard L. Wiener \& Eve M. Brank eds., 2013).

19. Kourlis et al., supra note 2, at 353.

20. Id.

21. Id.

22. Id. at $353,370-71$.

23. See Babb, supra note 7, at 507-18 (1998); David B. Wexler, The Development of Therapeutic Jurisprudence: From Theory to Practice, 68 ReV. JuR. U.P.R. 691 (1999); see also BronFEnBRENNER, supra note 14; Babb \& Wexler, supra note 7.

24. Id.

25. Babb, supra note 7.

26. Kourlis et al., supra note 2, at 353.

27. Id.

28. Id.

29. Id. at 354 .

30. Id.

31. Id.

32. Id.

33. Id. at 368.

34. Babb, supra note 7.

35. Babb, Interdisciplinary Framework, supra note 7.

36. Id. at 492.

37. See generally Babb, supra note 35 .

38. Barbara A. BABb, Unified Family Court Connection 3 (The Ctr. for Families, Children and the Courts 2007).

39. Id.

40. Robert M. Bell, Administration of Justice, 32 MD. B.J. 2, 4, (1999).

41. Kourlis et al., supra note 2, at 368 .

42. See, e.g., MD. CoDE ANN. tit. $16 \S 202$ (West 2014).

43. Report of the Florida Supreme Court Gender Bias Study Commission 77 (1990), reprinted in 42 FLA. L. REV. 15, 18 (1990); Naomi R. Cahn, Family Law, Federalism, and the Federal Courts, 79 IowA L. Rev. 1073, 1091 (1994). Both publications discuss judges' extreme disdain toward family law assignment.

44. Kourlis et al., supra note 2, at 370 .

45. Id.

Barbara A. Babb is an associate professor of law and the founder and director of the Sayra and Neil Meyerhoff Center for Families, Children and the Courts at the University of Baltimore School of Law, where she has taught various family law courses since 1989. Her interdisciplinary scholarship focuses on therapeutic jurisprudence, the ecology of human development, court reform in family law, and the creation of unified family courts. She has written and spoken extensively at the state, national, and international levels, and she has participated in many court and law reform projects. She is a member of the Editorial Advisory Board of Family Court Review. She is a graduate of Cornell Law School and also holds an M.S. from Cornell University and a B.S. from the Pennsylvania State University. 
Copyright of Family Court Review is the property of Wiley-Blackwell and its content may not be copied or emailed to multiple sites or posted to a listserv without the copyright holder's express written permission. However, users may print, download, or email articles for individual use. 